\title{
Ministérios como "barganha": coalizão de governo e organização do Poder Executivo
}

\author{
Jaqueline da Silva Borges \\ Instituto de Pesquisa Econômica Aplicada (Ipea) \\ Sheila Cristina Tolentino Barbosa \\ Universidade de Brasília (UnB) e Instituto de Pesquisa Econômica Aplicada (Ipea)
}

No contexto do presidencialismo de coalizão com crescente número de partidos envolvidos, o poder de "barganha" do presidente para assegurar a governabilidade possui implicações sobre aspecto estrutural dos mandatos e, consequentemente, sobre a capacidade estatal na entrega de bens e serviços à sociedade. Pouco se discute quanto aos efeitos da distribuição de poder sobre a organização da administração pública. Este trabalho buscou, de modo exploratório, descrever possíveis correlações entre o tamanho das coalizões de governo e a dinâmica das transformações do gabinete. A análise comparativa aqui empreendida percorre 72 anos de história política e administrativa, contrastando períodos democráticos em diferentes contextos político-partidários. Os resultados da pesquisa indicam que as trajetórias das coalizões de governo e da estrutura do Poder Executivo federal estão correlacionadas. Em geral, o aumento do número de partidos na coalizão é acompanhado de expansão do número de pastas ministeriais. De outro lado, diminuições do número de partidos nas coalizões são paralelas à diminuição ou manutenção da composição do gabinete. Esses resultados suscitam o debate quanto às consequências dessas transformações sobre as condições e resultados da ação estatal.

Palavras-chave: Poder Executivo Federal, sistema de governo, política de governo, presidencialismo de coalizão, pluralismo partidário, articulação política, Brasil

[Artigo recebido em 17 de julho de 2018. Aprovado em 7 de fevereiro de 2019.] 


\section{Ministerios como "barganha": coalición de gobierno y organización del poder ejecutivo}

En el contexto del presidencialismo de coalición con creciente número de partidos involucrados, el poder de "negociación" del presidente para asegurar la gobernabilidad tiene implicaciones sobre aspecto estructural de los mandatos y, consecuentemente, sobre la capacidad estatal en la entrega de bienes y servicios a la sociedad. Poco se discute en relación a los efectos de la distribución de poder sobre la organización de la administración pública. Este trabajo buscó, de modo exploratorio, describir posibles correlaciones entre el tamaño de las coaliciones de gobierno y la dinámica de las transformaciones del gabinete. El análisis comparativo aquí emprendido recorre 72 años de historia política y administrativa, contrastando períodos democráticos en diferentes contextos político-partidarios. Los resultados de la investigación indican que las trayectorias de las coaliciones de gobierno y de la estructura del Poder Ejecutivo federal están correlacionadas. En general, el aumento del número de partidos en la coalición va acompañado de la expansión del número de ministerios. Por otro lado, disminuciones del número de partidos en las coaliciones son paralelos a la disminución o mantenimiento de la composición del gabinete. Estos resultados suscitan el debate sobre las consecuencias de esas transformaciones sobre las condiciones y resultados de la acción estatal.

Palabras claves: Poder Ejecutivo Federal, sistema de gobierno, política de gobierno, presidencialismo de coalición, pluralismo partidista, articulación política, Brasil

\section{Ministries as a resource to bargain: coalition of government and organization of executive power}

In the context of coalition presidentialism with a growing number of parties involved, the president's bargaining power to ensure governability has implications for the structural aspect of mandates and, consequently, for state capacity to deliver goods and services to society. There isn 't substantial discussion about the effects of the distribution of power on organization of public administration. This paper explores the possible correlations between the size of government coalitions and the dynamics of cabinet transformations. The comparative analysis observes 72 years of political and administrative history, contrasting democratic periods in different politicalpartisan contexts. The research results indicate that the trajectories of the government coalitions and the structure of Federal Executive Branch are correlated. In general, an increase at number of parties at coalition is followed by an increase at number of ministers. On the other hand, decreases at number of parties in the coalitions are correlated to decrease or maintenance of the composition of the cabinet. These results raise a debate about the consequences of these transformations on conditions and results of government's action.

Keywords: Poder Executivo Federal, system of government, government policy, coalition presidentialism, party pluralism, political articulation, Brazil 


\section{Introdução}

Os resultados obtidos pelo Estado nos diferentes governos, amplamente discutidos pela Ciência Política nos estudos sobre políticas públicas, são influenciados por múltiplos aspectos, inclusive pelo aspecto estrutural dos mandatos. Ou seja, da face organizacional dos governos enquanto delimitadora de capacidades estatais na entrega de bens e serviços à sociedade.

No caso brasileiro, observa-se que em um contexto de presidencialismo de coalizão com crescente número de partidos envolvidos, o poder de "barganha" ${ }^{1}$ do presidente para assegurar a governabilidade possui implicações sobre o aspecto estrutural dos mandatos e, consequentemente, sobre a capacidade estatal. Assim, esforços para compreensão de possíveis relações entre coalizões de governo e aspectos estruturais dos mandatos ganham relevância.

Ao ter por pressuposto que o poder do Presidente da República em nomear seus ministros seja um poder de "barganha" para assegurar a governabilidade e que, do ponto de vista estrutural, pastas ministeriais são entendidas enquanto um aspecto relevante para formulação e implementação das políticas, este trabalho busca, de modo exploratório, descrever possíveis correlações entre transformações das pastas ministeriais e o tamanho das coalizões de governo². A análise comparativa aqui empreendida percorre 72 anos de história político-administrativa, contrastando períodos democráticos em diferentes contextos político-partidários, a partir de referenciais teóricos relativos a presidencialismo de coalizão e organização do aparato administrativo do Estado, especificamente do Poder Executivo federal.

A compreensão de transformações que ocorreram na administração pública federal, objetivo central de uma pesquisa mais ampla a qual este artigo pertence, mostra-se relevante para analisar, dentre outros aspectos, a capacidade estatal.

Para a consecução dos objetivos propostos, utilizou-se metodologia qualitativa e comparativa para análise dos governos da Quarta República Brasileira (1945-1964) e Sexta República Brasileira (1985-2016). Além de restringir-se a formação inicial e final de cada governo ${ }^{3}$, a análise é restrita à observação da administração pública federal direta.

\footnotetext{
${ }^{1}$ Embora a barganha seja conceituada por alguns autores como uma carta-branca dada aos ministros em troca de apoio parlamentar (Bersch; Praça; Taylor, 2013), neste texto ela é entendida como parte de uma articulação política mais complexa. Não se trata de pressupor de antemão que, pelo fato de um partido deter um ministério, ele conseguirá emplacar a sua agenda, independentemente da vontade do presidente.

${ }^{2}$ Coalizões de governo compreendem os atores partidários (ou não) que ocuparam cargos em troca de apoio parlamentar.

${ }^{3}$ Para sinalizar governos consecutivos de um mesmo presidente nos gráficos, foram utilizados números romanos.
} 
Os resultados da pesquisa indicam que as trajetórias das coalizões de governo e da estrutura do Poder Executivo federal estão correlacionadas. Em geral, o aumento do número de partidos na coalizão é acompanhado de expansão do número de pastas ministeriais. De outro lado, diminuições do número de partidos nas coalizões são paralelas à diminuição ou manutenção da composição do gabinete. Esses resultados suscitam o debate quanto às consequências dessas transformações sobre as condições e resultados da ação estatal. A compreensão das relações entre os contextos organizacionais delineados pela pesquisa e os resultados da ação estatal é tarefa para estudos adicionais.

Este texto está organizado da seguinte forma: a próxima seção apresenta a base teórica que estruturou a análise dos dados. Na sequência, o item 3 traz uma breve descrição da metodologia utilizada. Na seção 4 são apresentados e discutidos os dados da pesquisa. Por fim, seguem as considerações finais, incluindo indicações de pesquisas futuras.

\section{Presidencialismo de coalizão brasileiro e pastas ministeriais}

Ao ter por pressuposto que o objetivo do presidente é assegurar apoio legislativo, a maioria dos estudos relacionados ao Poder Executivo se preocupa em analisar os ministérios como instrumentos de "barganha" presidencial para gerenciar maiorias legislativas (AMorim Neto; Cox; McCubbins, 2003; AMorim Neto, 2006; Pereira; POWER; RAILE, 2011). Pouco se discute quanto aos efeitos do presidencialismo de coalizão sobre a organização da administração pública federal e, consequentemente, sobre seus efeitos na capacidade estatal.

Dentre os poucos estudos dessa agenda de pesquisa, tem-se a análise empreendida por Inácio e Llanos (2016) e Vieira (2014), que analisam a organização estrutural da Presidência.

Há, segundo Inácio e Llanos (2016), três justificativas para as transformações da Presidência institucional": "[...] aumento das responsabilidades do governo, a reafirmação da liderança presidencial vis-à-vis o ambiente político (Congresso e público em geral), e uma gestão mais astuta da política do gabinete." (INÁcIO; LLANOS, 2016, p. 3) ${ }^{5}$. A configuração partidária de um determinado governo, como argumentam as autoras, também reflete na administração de recursos disponíveis aos presidentes. Dito de outro modo, para além das nomeações e poder de agenda, Inácio e Llanos (2016) entendem o poder de reorganização da

\footnotetext{
4 "Institutional presidency refers to the bulk of agencies that operate under direct presidential authority and are in charge of supporting the presidential leadership." (Inácio; Llanos, 2016, p.1)

${ }^{5}$ Tradução nossa.
} 
Presidência institucional como um trunfo ao qual o presidente pode recorrer para gerir coalizões. Isso porque em governos multipartidários há a necessidade de um "núcleo de governo" maior, uma vez que haverá maior compartilhamento de cargos e necessidade de gerenciamento da coalizão.

Além disso, as autoras têm como hipótese que instabilidade econômica e política, tamanho da base no Congresso e ausência/presença de mecanismos constitucionais de coordenação refletem na organização da Presidência institucional.

Ao investigar fatores que explicariam o aumento e/ou diferenciação da pasta de seis Presidências institucionais latino-americanas ${ }^{6}$, as autoras pontuam que as alterações observadas na expansão/diminuição são reflexos da natureza da agenda do presidente. Além disso, em cenários de coalizão, onde se tem a necessidade de gerenciar e compartilhar posições, é mais provável que haja expansão das pastas da Presidência. A relação negativa entre quantidade de ministérios e tamanho da Presidência institucional também traz indícios de maior centralização de funções e pastas. Ou seja, quando há mais ministérios e menor a Presidência, entende-se que o presidente, em um cenário de maior coesão partidária, delegaria mais aos seus ministros.

Vieira (2014) traz contribuição para essa discussão ao analisar fatores que explicariam a criação de burocracias centralizadas na Presidência, entre 1990 e 2009. Segundo o autor, a probabilidade de criação de estruturas burocráticas ligadas à Presidência aumenta conforme o grau de conflito de preferências entre o Presidente e membros da coalizão.

Guardadas possíveis distinções entre os sistemas de governo, a análise de alterações ministeriais britânica, de 1979 e 2009, feita por White e Dunleavy (2010), traz problematizações relevantes para este artigo. Teriam, segundo os autores, três influências a serem consideradas nas reorganizações ministeriais: "[...] pressões externas, desafios administrativos, considerações políticas e ponderações quanto à formação do gabinete." (WHITE; DUNLEAVY, 2010, p.11)7. Ou seja, alterações em pastas ministeriais seriam reflexos das dinâmicas políticas e administrativas.

A intenção de adaptar o governo para contemplar metas políticas e administrativas de longo prazo estaria entre fatores mencionados pelos entrevistados que explicam as alterações mais eficazes. Mas mais do que isso, novas pastas ministeriais representam uma oportunidade de recompensar aliados e estabelecer novas prioridades governamentais. Quando havia divergências entre a alocação política das pastas e atendimento de necessidades de longo prazo do gabinete, sem

\footnotetext{
${ }^{6}$ Argentina, Brasil, Colômbia, México, Paraguai e Uruguai.

${ }^{7}$ Tradução nossa.
} 
acrescer demais o número de pastas, um entrevistado (citado no estudo de White e Dunleavy, 2010) mencionou que a decisão era tomada de modo rápido, favorecendo a preferência de ministros. Além de a questão política ser o fator mais citado como determinante das reconfigurações entre 1979 e 2009 (48\%), "delivery" e "policy" são mencionados, com $29 \%$ e $23 \%$ respectivamente.

Na mesma linha, Davis, Weller, Crasswell e Eggins (1999) entendem que as alterações observadas nos gabinetes entre 1950 e 1997 na Austrália, Canadá e Reino Unido são reflexos de cálculos políticos e administrativos. Ainda que a correlação entre partidos e alterações nas pastas seja fraca para os gabinetes canadense e britânico, todos os países em análise possuem uma forte correlação entre eleições, novos primeiros-ministros e alterações ministeriais.

Indo ao encontro das influências mencionadas por White e Dunleavy (2010), Pollitt (1984 apud Public Administrative Select CommitTee, 2007), em análise do caso britânico também, pontua que uma parcela considerável das alterações observadas era decorrente do maior peso a uma determinada política, em busca de uma eficiência administrativa:

A recente reorganização em pequena escala para criar um ministério do Terceiro Setor no Gabinete de Governo é um exemplo: a reorganização uniu a Diretoria de Comunidades Ativas do Ministério do Interior com a Unidade de Empreendimento Social, que era abrigada no Departamento de Comércio e Indústria. Isso reflete a importância que o governo atribui atualmente ao trabalho com o Terceiro Setor, e coincidiu com a designação de um Ministro para o Terceiro Setor. (COMITÊ SELETIVO DE ADMINISTRAÇÃO PÚBLICA, 2007) ${ }^{8}$

Tendo em vista aspectos trazidos pela literatura que analisam casos parlamentaristas ecom intuito deavançarnessa discussãoem países presidencialistas, este trabalho pretende problematizar, de modo exploratório, as transformações das pastas ministeriais do Poder Executivo e a sua possível correlação com a formação partidária do gabinete.

Embora pouco se verse sobre estrutura organizacional do governo na Ciência Política, esta determina a hierarquia, distribuição de competências e alocação de recursos. Ou seja, repercute sobre as práticas e interações humanas (HALL, 1996). Na organização da administração pública, a estrutura organizacional tem implicações na distribuição de recursos humanos e orçamentários para consecução dos objetivos governamentais, bem como representa a distribuição de poder na arena política. Assim, a observação do modo de organização governamental é particularmente esclarecedora sobre capacidades estatais (HOWLETT, 2013). Nesse

\footnotetext{
${ }^{8}$ Tradução nossa.
} 
sentido, a dinâmica de equilíbrio do sistema político influencia as condições e resultados da ação estatal, na medida em que, de acordo com Bryner (2010, p. 316), "[...] os êxitos e fracassos burocráticos são consequências da distribuição de poder na economia política de que fazem parte".

Ainda que não seja a abordagem desta análise, é importante destacar também que, como ocorre em outros fenômenos sociais, reconhece-se a multicausalidade que perpassa as transformações na organização da administração pública. Como destacam Tachizawa e Scaico (2006), não só os contextos políticos, mas também os sociais e econômicos determinam a continuidade ou interrupção de arranjos organizacionais.

\section{Metodologia}

Para a consecução dos objetivos propostos, utilizou-se metodologia qualitativa e comparativa de governos entre os anos 1945 e 2016, cobrindo 72 anos de história política e organizacional do Poder Executivo federal. A análise empreendida compara as formações iniciais e finais do gabinete ministerial de cada governo ${ }^{9}$, para descrever a transformação organizacional da transição de um governo a outro em um cenário multipartidário. A pesquisa restringiu-se a observar modificações no primeiro nível organizacional do Poder Executivo federal, descrito pelo conjunto de pastas ministeriais. Dito de outro modo, restrita à observação da administração pública federal direta.

Nesta análise, não se considera o tempo de permanência de cada ministro, mas o processo de ocupação a cada transição de governo, na medida em que este seria o momento de maiores modificações nas coalizões e potencialmente com maiores reflexos sobre as pastas ministeriais ${ }^{10}$.

As informações sobre pastas ministeriais e ministros foram coletadas da Biblioteca da Presidência da República e Hippolito (1985). Além disso, recorreuse às medidas provisórias e leis ordinárias para compreender as alterações na organização do Poder Executivo.

Para mensurar partidos que compõem a coalizão de governo tem-se como base a filiação partidária de ministro e secretários que ocuparam pastas. Essas informações foram coletadas de Hippolito (1985) e do Dicionário Histórico-Biográfico Brasileiro (DHBB) do Centro de Pesquisa e Documentação de História Contemporânea do Brasil da Fundação Getúlio Vargas (CPDOC-FGV). As bancadas da Câmara dos Deputados que são analisadas, foram extraídas de Hippolito (1985) e do Tribunal Superior Eleitoral (TSE).

\footnotetext{
${ }^{9}$ Para sinalizar governos consecutivos de um mesmo presidente nos gráficos, foram utilizados números romanos.

${ }^{10}$ Embora ocorram modificações pontuais da composição do gabinete durante os mandatos, essas não foram objeto dessa discussão.
} 
Cabe ressalvar, de todo modo, possíveis limitações dessa definição partidária na medida em que ser filiado a um partido não implica que o partido ao qual o ministro pertença apoie o governo ${ }^{11}$. Figueiredo (2007) reconhece essa limitação metodológica, uma vez que a posição dos partidos não é completamente disponível. Mas entende como viável em um estudo de caso explorar esse aspecto.

O recorte temporal teve como parâmetro as duas últimas constituições democráticas. O primeiro período analisado é marcado pela promulgação da Constituição de 1946 e termina em março de 1964, com a instauração da ditadura militar. $\mathrm{O}$ segundo período contempla a constituição vigente atualmente, promulgada em $1988^{12}$. Esses dois períodos com contextos bastante distintos viabilizam comparações de contraste quanto ao tamanho das coalizões e número de partidos que possuem representação na Câmara dos Deputados.

Os governos militares não foram contemplados no escopo desta pesquisa com a mesma profundidade que os períodos democráticos. Ainda que possa ser interessante analisar como seria a organização ministerial em um cenário em que não há incentivos partidários, a reconfiguração do sistema partidário observado nessa época não se mostrou rentável para análise de coalizões de governo ${ }^{13}$. Portanto, o artigo traz apenas dados sobre a estrutura ministerial e composição partidária da Câmara dos Deputados desse período, a título de contextualização com o governo que antecede e sucede a ditadura militar.

\section{Transformações das pastas ministeriais do Poder Executivo brasileiro (1945-2016)}

Esta seção está subdividida em duas partes. Primeiramente, será realizado um panorama geral do quantitativo de pastas ministeriais e organização partidária do Poder Executivo. Posteriormente, será realizada uma análise comparando as formações iniciais e finais de cada governo, para traçar o impacto da transição de um governo a outro em um cenário multipartidário.

\footnotetext{
${ }^{11}$ Era o caso da UDN, durante o governo Vargas. O apoio à nomeação do pernambucano João Cleofa foi regional, embora a nível nacional o partido se colocasse como oposição ao governo. Outro exemplo desse conflito intrapartidário é a posição do PMDB nos governos pós 1988 (Figueiredo, 2007).

${ }^{12}$ Ainda que não seja objeto de análise deste artigo, reconhece-se a relevância analítica do período militar para desdobramentos futuros da pesquisa. Na medida em que o presidente não teria a necessidade de formar maiorias legislativas para governar, vale investigar qual seria a estratégia de composição e alocação de pastas.

${ }^{13} \mathrm{O}$ regime militar permitiu a existência de apenas dois partidos: Aliança Renovadora Nacional (Arena) e o Movimento Democrático Brasileiro (MDB). Havia outros partidos na clandestinidade.
} 


\section{Panorama geral}

A combinação de diferentes arranjos institucionais e suas implicações para a estabilidade democrática e relação harmônica entre poderes tem sido objeto de diversas análises. Contrapondo a literatura precursora (LINZ, 1985), estudos como o de Mainwaring e Shugart (2002), Limongi e Figueiredo (1998) e Cheibub e Limongi (2002) trazem evidências empíricas que atestam o grau de cooperação entre poderes e consequente governabilidade.

Cheibub e Limongi (2002) apontam a insuficiência em se atentar para princípios básicos dos sistemas políticos sem observar dispositivos institucionais que influenciariam na dinâmica da gestão, como, por exemplo, as coalizões em regimes presidencialistas. Tais coalizões podem ser governamentais ou legislativas (FIGUEIREDO, 2007). Enquanto a coalizão legislativa relaciona-se a uma negociação ad hoc ou uma união de partidos em decorrência de preferências políticas, coalizões de governo compreendem os atores partidários (ou não) que ocuparam cargos em troca de apoio parlamentar.

Presentes em muitos países da América Latina (MARTINEZ-GALLARDo, 2010), as coalizões de governo seriam eficientes em assegurar apoio parlamentar. Ao mensurar o comportamento legislativo dos integrantes da coalizão, os resultados de Amorim Neto (2000) apontam que há disciplina partidária quando a taxa de

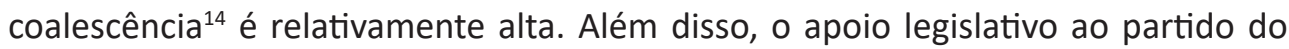
presidente tende a diminuir no decorrer de sua gestão, e quanto maior a distância ideológica entre o partido do presidente e integrantes da coalizão, menor será a probabilidade de apoio legislativo.

O Gráfico 1 traça um panorama do tamanho das coalizões de governo de 1945 a 1964 e 1985 a 2016 no Brasil. Além disso, traz informações acerca da quantidade de siglas e número de partidos efetivos ${ }^{15}$ com representação na Câmara dos Deputados. Um dos primeiros pontos a se destacar, de modo geral, é que apesar de elevada quantidade de siglas com representação no legislativo, o número de partidos efetivos na Câmara e o tamanho da coalizão apresentam valores próximos. Como não faz sentido falar em coalizão de governo em período ditatorial, o Gráfico 1 traz, apenas a nível de comparação, a quantidade de siglas e o número de partidos efetivos que, como já é esperado, ficam em torno de dois partidos.

\footnotetext{
${ }^{14}$ Amorim Neto (2000) define taxa de coalescência como uma variável contínua que mede a proporcionalidade entre a quantidade de pastas ministeriais e o respectivo quantitativo de assentos no legislativo. Quanto maior essa proporcionalidade, mais coalescente é o gabinete.

${ }^{15}$ Para mensurar o número de partidos efetivos, foi utilizada a fórmula de Laakso e Taagepera (1979). A vantagem de usar essa fórmula, em vez de apenas contabilizar os quantitativos de partidos que possuem representação na Câmara dos Deputados, é devido à sua capacidade de distinguir partidos que sejam de fato significativos daqueles com bancadas menos expressivas.
} 
No período entre 1945 e 1964, de Dutra até Goulart, a quantidade de partidos que compõe o governo oscila entre dois e quatro. Após a redemocratização, em 1985, há alterações na característica da coalizão, com acréscimo de partidos compondo a gestão, tendo seu ápice no segundo mandato de Lula. Essa ascendência do tamanho da coalizão de governo e número de partidos efetivos só não é mais expressiva do que a quantidade de siglas. Evidencia-se, assim, a cautela necessária ao observar o mero quantitativo de partidos com representação na Câmara.

\section{Gráfico 1 - Tamanho da coalizão de governo (1945-2016)}

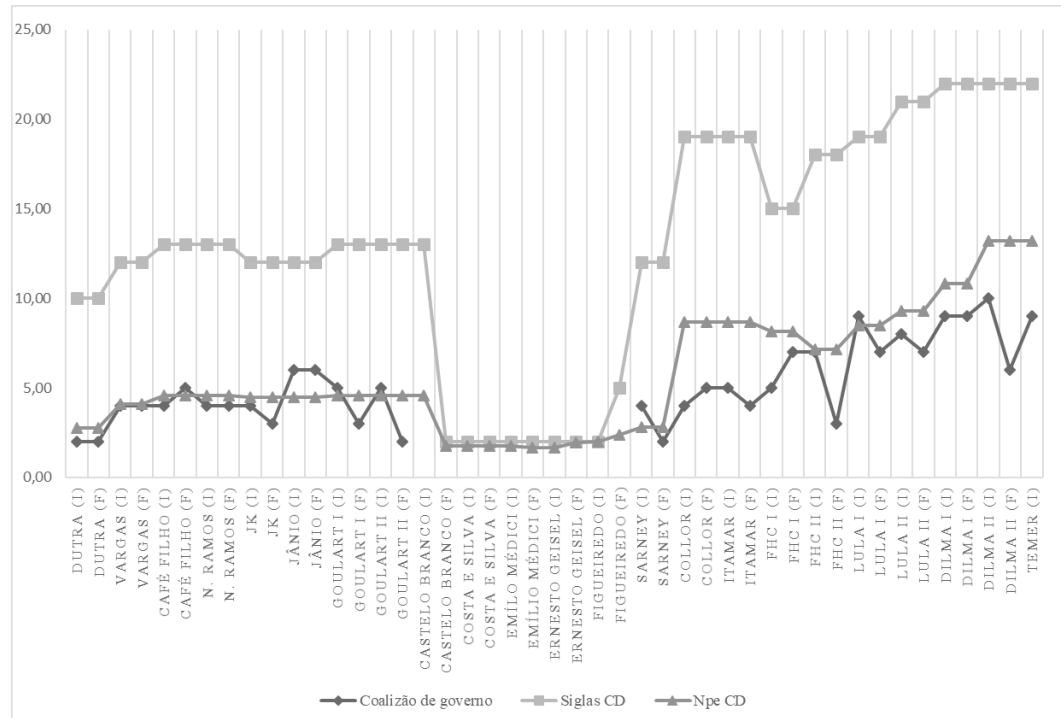

Fonte: elaboração própria a partir de base de dados própria e Tribunal Superior Eleitoral.

NpE: Número de partidos efetivos da Câmara dos Deputados

(I) Formação inicial; (F) Formação final

Ainda que este trabalho não tenha por objetivo analisar alterações na composição da coalizão no decorrer de um mesmo mandato, dados de Figueiredo (2007), Inácio e Rezende (2015) e Darrieux (2015) permitem apontar que, guardada algumas pequenas diferenças em alguns momentos, os tamanhos da coalizão até 2014 não são completamente distintos daqueles observados nas transições. Além disso, como já é observado no Gráfico 1, há proximidade entre número de partidos efetivos da Câmara dos Deputados e tamanho das coalizões de governo.

O Gráfico 2 traz informações sobre a quantidade de ministérios e órgãos da Presidência com e sem status ministerial nos governos em análise. O primeiro ponto a ser destacado é a estabilidade que marca os governos entre Dutra e Goulart (19451964). Há o acréscimo de alguns ministérios, enquanto os órgãos da Presidência sofrem modificações apenas no governo de Goulart. É no mandato de Goulart que 
há também o surgimento dos primeiros ministros extraordinários. Esses cargos não implicam na alocação de estrutura própria para o tema sob sua competência, sendo dotado de status ministerial.

Durante o período militar, apenas a título de comparação, observa-se certa estabilidade no número de pastas. A possível relação entre pastas ministeriais e coalizão não é passível de análise.

\section{Gráfico2 - Transformações de pastas ministeriais do Poder Executivo (1945-2016)}

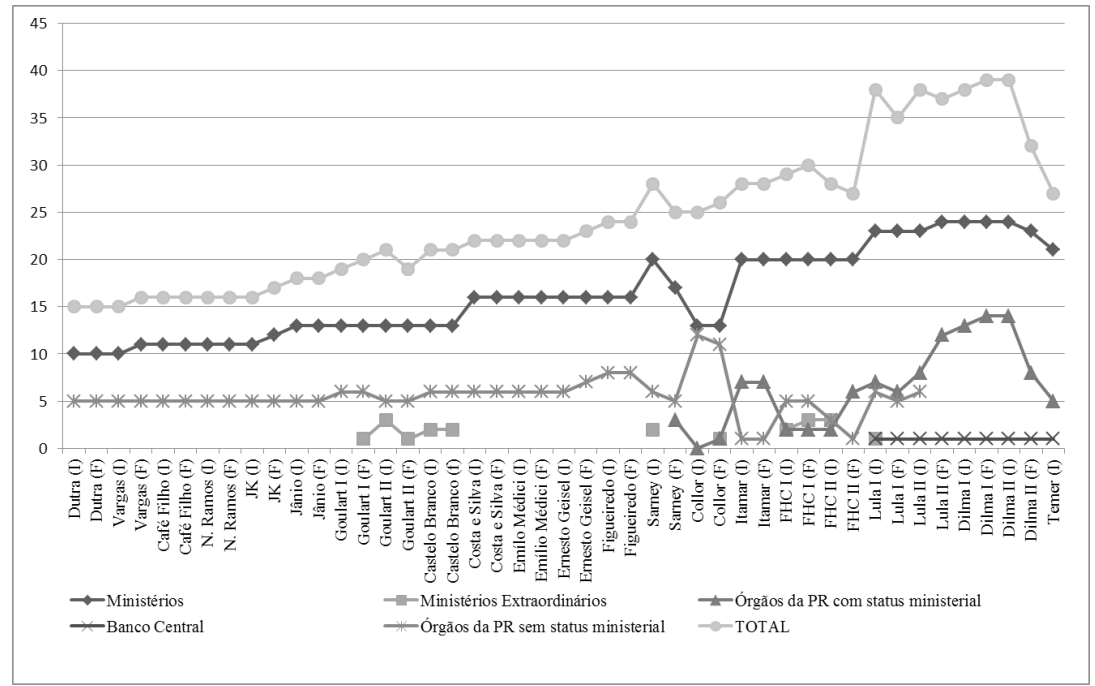

Fonte: elaboração própria a partir de dados da Biblioteca da Presidência da República.

(I) Formação inicial; (F) Formação final

Mudanças significativas ocorrem pós-redemocratização, em 1985. Em Sarney aumenta a quantidade de ministérios, voltando a decrescer em Collor. Entre os governos de Itamar Franco e Fernando Henrique Cardoso há certa estabilidade na quantidade total de ministérios. O ápice do aumento da quantidade acontece ao fim do segundo mandato de Lula, com vinte e quatro ministérios. Ao incluir órgãos ligados à Presidência com status ministerial na contagem, o maior quantitativo de pastas ministeriais do Poder Executivo é observado no fim do primeiro mandato de Dilma Rousseff.

Os órgãos ligados diretamente à Presidência também apresentam diferenças significativas pós 1985, indicando mudança de estratégia organizacional. Além da quantidade que se altera no decorrer das transições de gestões, a partir de Sarney alguns órgãos ganham status ministerial. Ao fim do segundo mandato de Lula, e nos mandatos subsequentes, todos esses órgãos detêm status ministerial. O Banco Central também ganha status ministerial no primeiro mandato de Lula. 
Ressalvadas algumas exceções, o Gráfico 2 evidencia que, no decorrer do período analisado, há uma trajetória crescente do número de ministérios e órgãos ligados diretamente à Presidência com status ministerial do Poder Executivo. Na medida em que há, conforme o Gráfico 1 sobre coalizões, aumento de atores partidários compondo as pastas ministeriais, seria possível traçar algum paralelo entre a expansão do número de ministérios e órgãos da Presidência com status ministerial?

No sentido de lançar luzes sobre essa possível relação, o Gráfico 3 traz a trajetória de três variáveis: número de ministérios ${ }^{16}$, ocupação partidária e coalizão de governo. $\mathrm{A}$ ocupação partidária refere-se à quantidade de pastas ministeriais que foram chefiadas por filiados a partidos políticos, enquanto a coalizão diz respeito à quantidade de partidos que fizeram parte do governo. Ressalvadas algumas oscilações entre início e fim de gestão, uma parcela significativa das pastas foi ocupada por filiados a partidos políticos. Além disso, eleva-se a quantidade de partidos que fizeram parte da coalizão de governo no período analisado. A análise de correlação linear de Pearson permite rejeitar a hipótese nula $(0,000)$ e se mostra significativa $(0,701)$. Ou seja, há elevada correlação entre quantitativo de pastas ministeriais e tamanho da coalizão.

\section{Gráfico 3 - Quantidade de ministérios e sua relação com a coalizão de governo} (1945-2016)

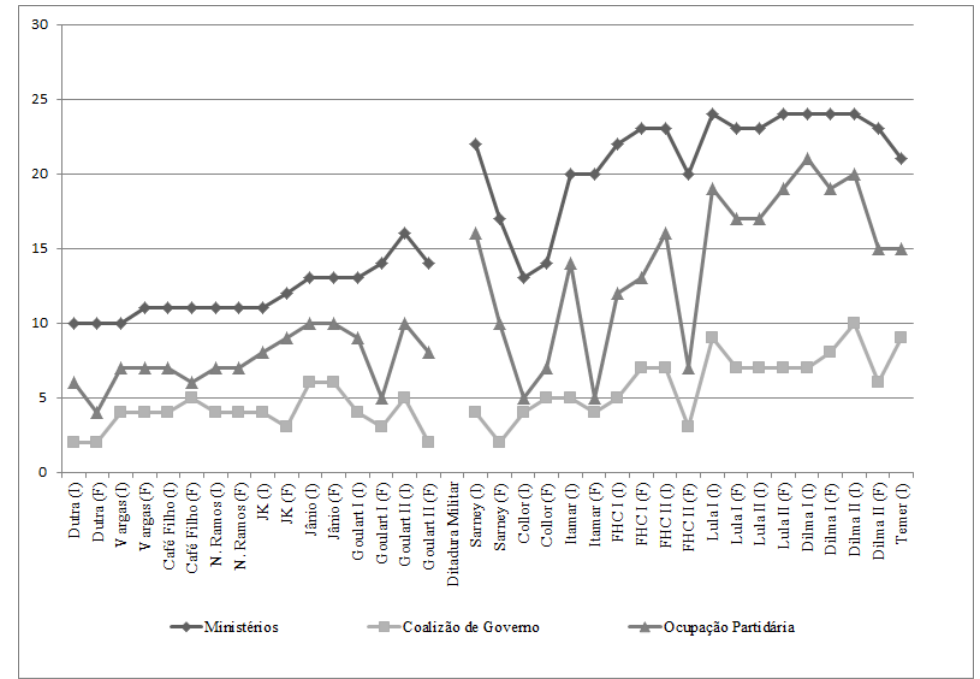

Fonte: elaboração própria a partir de dados da Biblioteca da Presidência da República.

(I) Formação inicial; (F) Formação final

Além de mostrar as curvas crescentes de ocupação partidária e de pastas dos ministérios, o Gráfico 3 também expõe alguns movimentos atípicos, como nos

${ }^{16}$ Considera-se na contagem os ministérios militares e ministros extraordinários. 
governos Dutra (F), Café Filho (F) e Itamar (I), em que há oscilações entre coalizão de governo e a ocupação partidária que não refletem transformações na quantidade dos ministérios. Além disso, a configuração ao fim de mandato também pode ser impactada pelas saídas de ministros por motivos eleitorais e sua substituição por interinos que não apresentam filiação partidária. Os órgãos da Presidência com status ministerial crescem substancialmente no período pós-redemocratização (vide Gráfico 4). Além disso, tais órgãos passam a ter maior ocupação partidária, ainda que quantitativamente não sejam muitos partidos. Nesse período, as pastas são, em sua grande maioria, ocupadas por filiados ao partido do Presidente. A correlação linear de Pearson, entre número de órgãos da Presidência com status ministerial e tamanho da coalizão, também permite rejeitar a hipótese nula $(0,000)$, com elevado coeficiente $(0,949)$.

\section{Gráfico 4 - Quantidade de órgãos da Presidência com status ministerial e sua relação com a coalizão de governo (1985-2016).}

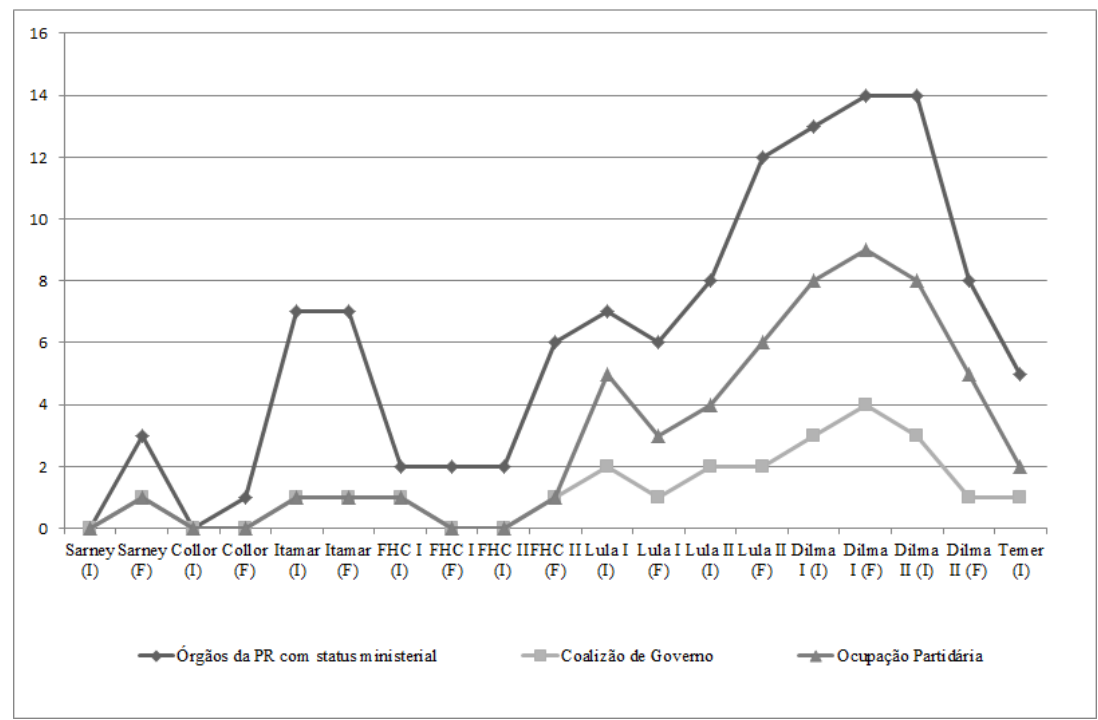

Fonte: elaboração própria a partir de dados da Biblioteca da Presidência da República.

(I) Formação inicial; (F) Formação final

As mudanças no status ministerial de tais órgãos e maior inserção de filiados ao partido do Presidente na sua ocupação podem ser explicadas, em parte, conforme já apontaram Inácio e Llanos (2016) e Vieira (2014), pela crescente relevância de um "núcleo de governo" capaz de gerenciar a coalizão.

Outro ponto a ser destacado é a inserção de pastas finalísticas, tais como direitos humanos, política para mulheres e promoção da igualdade racial no rol de órgãos da Presidência com status ministerial. A trajetória de transformação organizacional 
dos órgãos da Presidência pode também sinalizar uma centralização da agenda estratégica de programas tais como o PAC e Minha Casa Minha Vida. Destaca-se que o decréscimo no número de tais órgãos observado no governo Temer é decorrente de aglutinações de estruturas, ou seja, da alocação das estruturas que tratam desses temas em outros ministérios, não implicando necessariamente em significativa redução de estrutura, mas tão somente do número de órgãos da Presidência com status ministerial.

Assim, embora tais gráficos tragam à tona alguns aspectos do contexto político que auxiliam na compreensão das transformações da organização do Poder Executivo federal, é importante ressaltar que outras questões tais como a plataforma programática do presidente, necessidade de ajuste fiscal ou crises econômicas e políticas são possibilidades contextuais a contribuir para tais transformações.

As transformações na organização da administração pública federal podem ser influenciadas por nuances produzidas pela distribuição de poder que sustenta as coalizões de governo em suas transições. Com intuito de descrever essa dinâmica, será feita na sequência uma análise comparativa da estrutura do gabinete e composição partidária nas transições de cada governo entre 1945 e 2016, exceto período militar.

\section{Formação ministerial e ocupação partidária: uma análise das transições de governos $^{17}$}

\section{Quarta República Brasileira - 1946-1964}

Como mencionado anteriormente, os governos desse período republicano são marcados por elevada estabilidade estrutural, além de se tratar de uma configuração partidária distinta da observada no período mais recente, com menor número de partidos efetivos. Ainda que não seja possível traçar um padrão claro sobre a relação entre a estrutura do gabinete e a formação partidária, ressaltam-se alguns aspectos a seguir.

Constituindo contexto singular, o partido de Dutra (Partido Social Democrático - PSD), Presidente entre os anos 1946 e 1950, detinha isoladamente a maioria das cadeiras da Câmara dos Deputados. Como os dados de Figueiredo (2007) já apontavam, houve algumas alterações na coalizão do governo de Dutra, que não foram acompanhadas de mudanças na estrutura do gabinete, mesmo porque o número de partidos na base permaneceu constante, com substituição de um partido por outro.

\footnotetext{
${ }^{17}$ Aqui está se considerando ministérios, ministérios militares, ministérios extraordinários e órgãos com status ministerial.
} 
Getúlio Vargas, eleito em 1950 pelo Partido Trabalhista Brasileiro (PTB), mantém a estrutura ministerial de seu antecessor, ainda que mais duas siglas passem a integrar o seu gabinete. Ao contrário do governo Dutra, o partido do presidente ocupa apenas um ministério: o Ministério do Trabalho, Indústria e Comércio. A porcentagem de cadeiras ocupadas pelo PTB na Câmara dos Deputados também apresenta relevante distinção: o partido ocupa apenas 16,8\%. Com a coalizão, Vargas forma um governo com partidos que totalizam $88,2 \%$ de assentos da Câmara dos Deputados.

Os governos subsequentes apresentam alguns incrementos na composição do gabinete e de siglas partidárias na coalizão de governo. Além disso, todos os governos do período possuem maioria legislativa, ao ter em consideração o tamanho das bancadas na Câmara dos Deputados dos partidos que compunham a coalizão de governo.

\section{Sexta República Brasileira - 1985-2016}

O gabinete de José Sarney, quando comparado com o governo de Figueiredo, último governo militar, apresenta um aumento de quatro ministérios e órgãos da Presidência com status ministerial ${ }^{18}$. Além disso, é a primeira gestão em que um desses órgãos possui status ministerial ${ }^{19}$.

Esse aumento na gestão de José Sarney é, possivelmente, uma questão de agenda em novo cenário político. A composição partidária da coalizão também traz tais indícios nesse sentido, na medida em que é formada por apenas dois partidos: Partido do Movimento Democrático Brasileiro (PMDB) e Partido da Frente Liberal (PFL). O partido do Presidente, que ocupa 53,4\% das cadeiras da Câmara dos Deputados, detém, ao fim de sua gestão, sete das vinte pastas ministeriais. Além disso, quase metade do gabinete é formado por não filiados a partidos políticos.

\footnotetext{
${ }^{18}$ Ministério do Desenvolvimento Urbano e Meio Ambiente, Ministério da Reforma e Desenvolvimento Agrário, Ministério das Comunicações, Ministério do Interior e Ministério dos Transportes.

${ }^{19}$ Ainda que não tenham feito parte da formação inicial e/ou final, três órgãos da Presidência ganharam status ministerial: Secretaria Especial de Ciência e Tecnologia, Secretaria de Planejamento e Coordenação e Secretaria de Administração Pública.
} 
Tabela 1 - Composição partidária de pastas ministeriais e formação legislativa

\begin{tabular}{|c|c|c|c|c|c|c|}
\hline & \multicolumn{3}{|c|}{ José Sarney (1985-1989) - PMDB } & \multicolumn{3}{|c|}{ Fernando Collor (1990-1992) - PRN } \\
\hline & \multicolumn{3}{|c|}{ Formação final } & \multicolumn{3}{|c|}{ Formação inicial } \\
\hline & $\begin{array}{l}\text { Qtde de } \\
\text { pastas }\end{array}$ & $\%$ pastas & $\% \mathrm{CD}$ & $\begin{array}{l}\text { Qtde de } \\
\text { pastas }\end{array}$ & $\%$ pastas & $\% \mathrm{CD}$ \\
\hline PMDB & 7 & 35,0 & 53,4 & 1 & 7,7 & 21,5 \\
\hline PFL & 4 & 20,0 & 24,2 & 2 & 15,4 & 16,5 \\
\hline PTB & 0 & 0,0 & & 1 & 7,7 & 7,0 \\
\hline PTR & 0 & 0,0 & & 1 & 7,7 & 0,4 \\
\hline $\begin{array}{l}\text { Não } \\
\text { filiados }\end{array}$ & 9 & 45,0 & & 8 & 61,5 & \\
\hline Total & 20 & $55,0 *$ & 77,6 & 13 & $38,5^{*}$ & 45,3 \\
\hline
\end{tabular}

*É desconsiderado nesse total a porcentagem de pastas ocupadas por não filiados.

Fernando Collor de Mello, filiado ao Partido da Reconstrução Nacional (PRN), foi o primeiro presidente da República eleito por voto direto pós-ditadura militar. Quando comparado com o governo de José Sarney, conforme a Tabela 1, há um decréscimo no número de ministérios. A redução está ligada a uma aglutinação de alguns ministérios ou transformação de alguns ministérios em secretarias e perda de status ministerial de órgãos ligados à Presidência. Ainda que tenha a presença de algumas secretarias temáticas, é perceptível o incremento de órgãos que visavam ao assessoramento e coordenação de assuntos ligados à Presidência. As modificações no decorrer da gestão, por sua vez, foram mais sutis. De acordo com Costa (2008), as transformações promovidas pelo governo Collor, na organização da administração pública, ocorrem de forma errática, sem referências conceituais ou elementos de estratégia, bem como de planejamento estruturado.

Apesar de haver um decréscimo na quantidade de pastas do governo de Fernando Collor em relação ao governo anterior, há mais partidos compondo o gabinete, quando comparado com o governo Sarney. Isso, entretanto, não implica em um governo majoritário: a coalizão totaliza no início do mandato $45,3 \%$.

Ao fim de seu mandato, há aumento de dois ministérios e alguns remanejamentos entre partidos e entre ministérios que eram ocupados por não filiados e passam a ser chefiados por filiados (e vice-versa). Assim, é possível supor que o incremento de partidos à coalizão no Governo Collor não implicou em aumento da estrutura do gabinete, mas, sim, um rearranjo das pastas para 
contemplar todos os membros da coalizão.

Em decorrência de um processo de impeachment, Fernando Collor renunciou em dezembro de 1992, e Itamar Franco (PMDB), seu vice, assumiu definitivamente a Presidência da República. Nesse cenário, a estrutura do Poder Executivo, que anteriormente contava com quinze pastas com status ministerial, passa a contar com vinte e sete (Tabela 02). Excetuando-se a Consultoria-Geral da União (que se transforma em Advocacia Geral da União), todos os órgãos da Presidência ganham status ministerial.

Ainda que a estrutura do gabinete tenha crescido substancialmente, em comparação com o governo Collor, o governo Itamar registra incremento de apenas uma sigla partidária no tamanho da coalizão. Seu gabinete é formado por cinco partidos, que somavam $54,7 \%$ dos assentos na Câmara dos Deputados. Isso indica que apesar de seguir a tendência de aumento do tamanho da coalizão e aumento do número de pastas ministeriais, fatores adicionais contribuíram para essa expansão, como, por exemplo, a recomposição do desmonte promovido por Collor, conforme comentado anteriormente.

Tabela 2 - Composição partidária de pastas ministeriais e formação legislativa

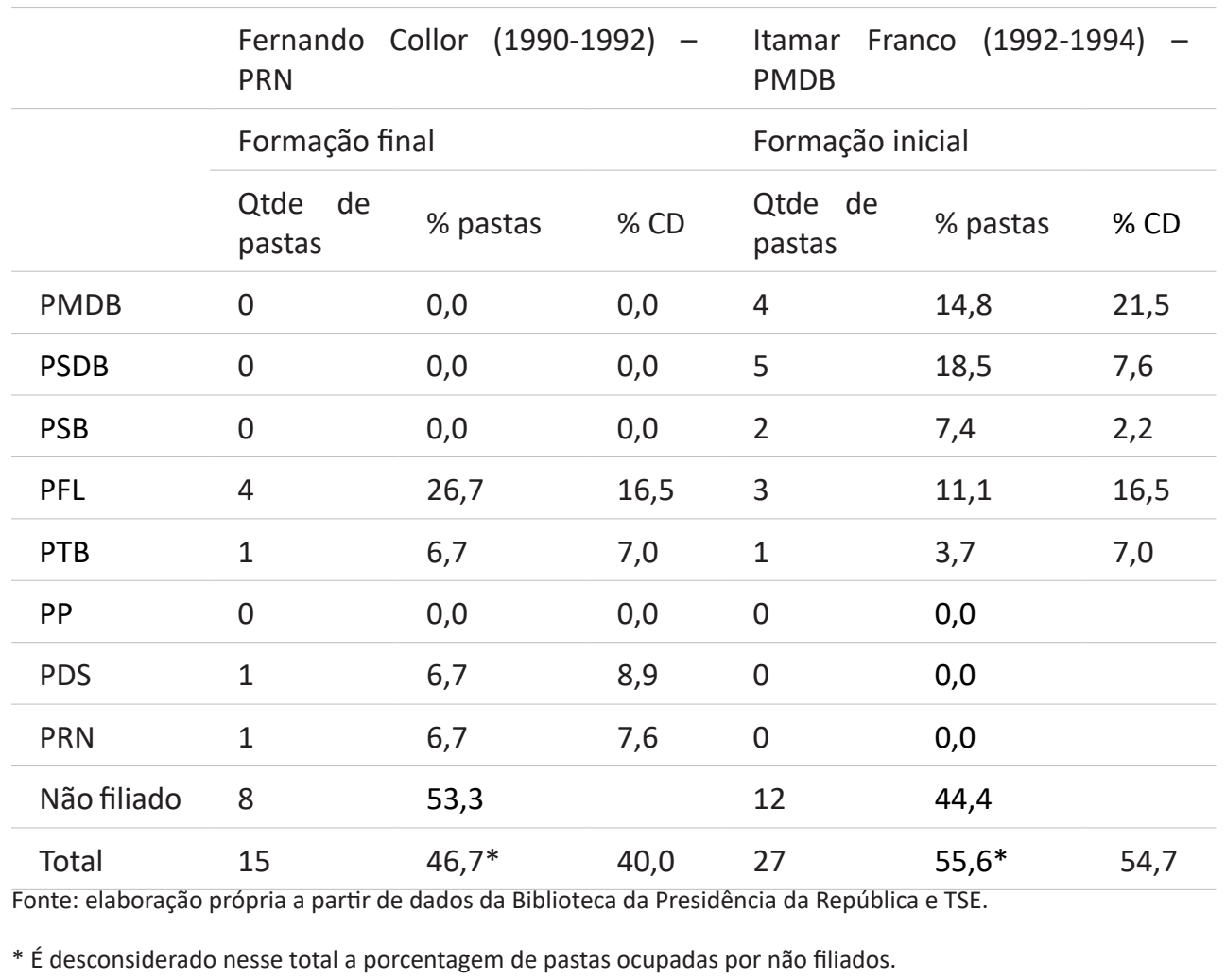


Ao fim do governo de Itamar, é perceptível uma reconfiguração da formação partidária do gabinete, onde o Partido Progressista (PP) entra e ocupa uma das pastas do Partido Socialista Brasileiro (PSB), que sai da coalizão. Além disso, conforme Tabela 3, há uma expansão de não filiados a partidos políticos nessa formação. Isso reflete na porcentagem de cadeiras que a coalizão ocupa na Câmara dos Deputados, a qual reduz para 45,6\%.

A coalizão na formação inicial de Fernando Henrique Cardoso, por sua vez, é acrescida de um partido, quando comparada à formação final do Governo Itamar, significando 63,7\% de assentos da Câmara dos Deputados. A estrutura organizacional da administração pública federal de seu governo contou com a inserção de dois ministros extraordinários e a diminuição do número de órgãos ligados diretamente à Presidência com status ministerial, que ao final resultou em redução de seu gabinete.

Tabela 3 - Composição partidária de pastas ministeriais e formação legislativa

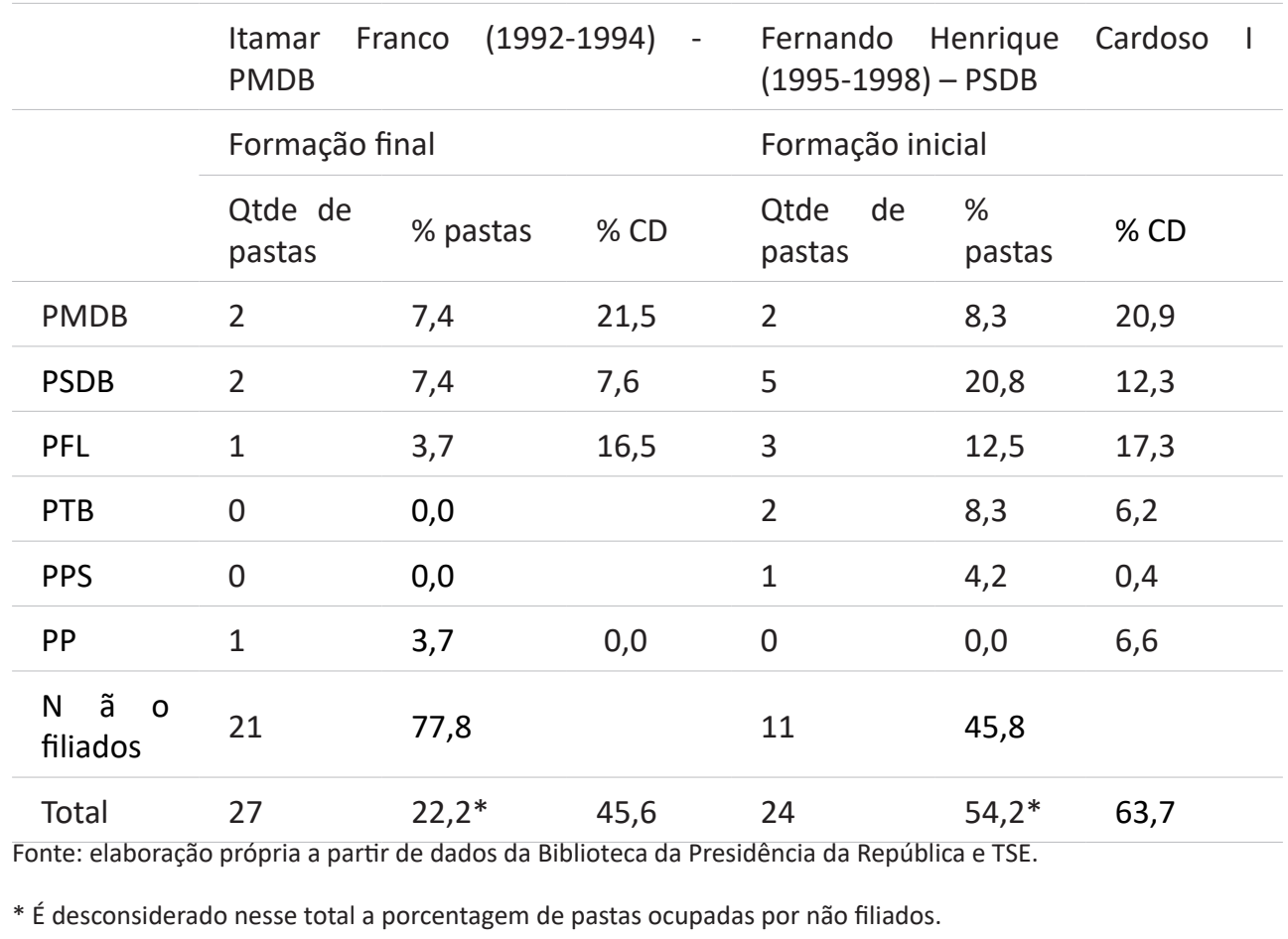

Com a inserção do Partido Progressista Brasileiro (PPB) na coalizão e acréscimo de um ministro extraordinário, filiado ao PFL, a formação final do primeiro mandato de Fernando Henrique Cardoso, conforme a Tabela 4, possui 57,1\% de apoio legislativo. Em comparação com a formação inicial, há o remanejamento partidário entre as pastas já existentes. Ao manter a coalizão e o tamanho do gabinete de seu primeiro mandato, começa seu governo tendo elevado apoio legislativo (74,3\%). 
Tabela 4 - Composição partidária de pastas ministeriais e formação legislativa

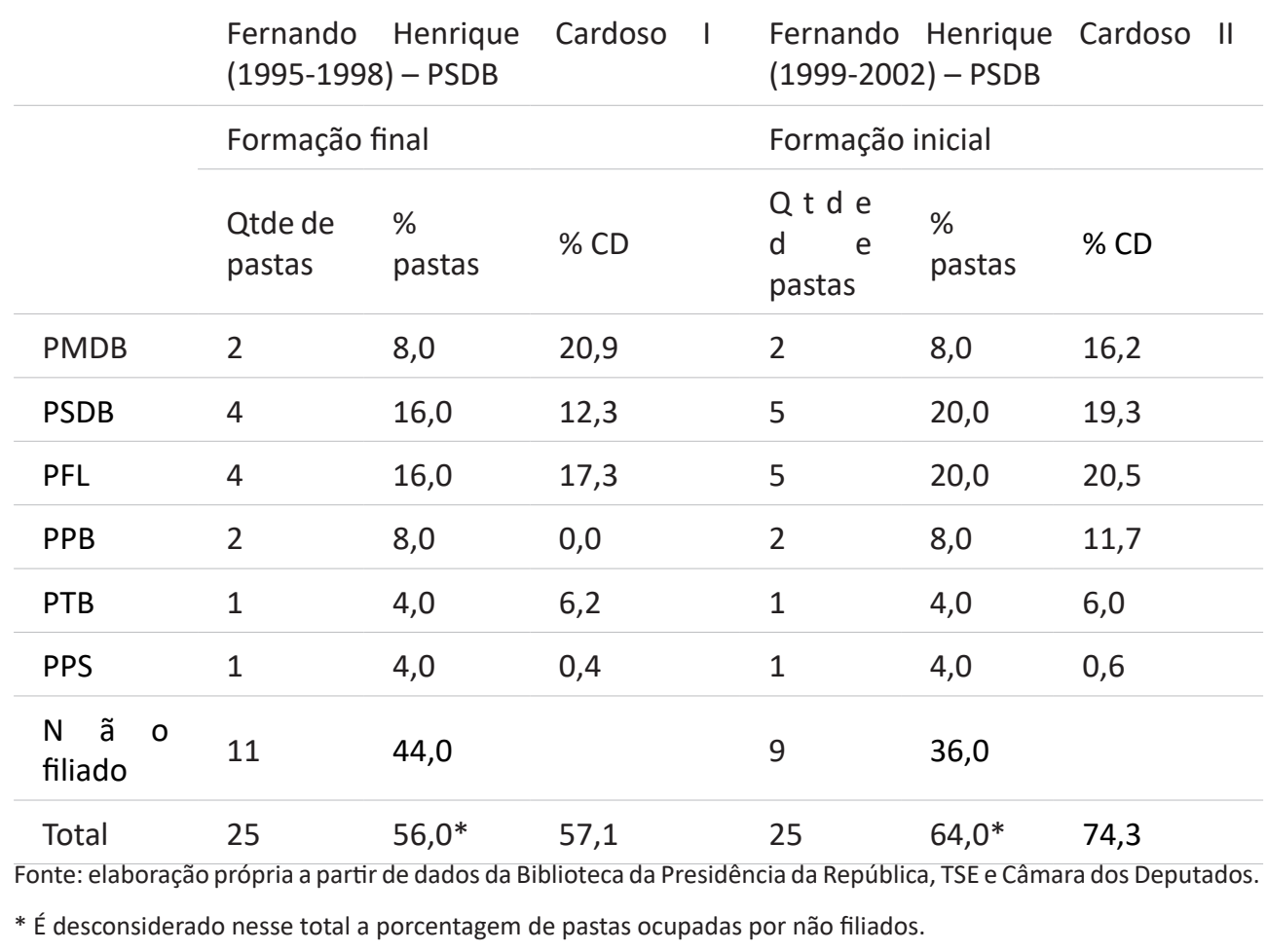

Ainda que quantitativamente não aparente, seu segundo mandato foi marcado por transformações e criações de estrutura. Ao fim do mandato de Fernando Henrique Cardoso, como pode ser observado na Tabela 5, entretanto, não há inserção de maispartidos, mas, como ocorre em mandatos anteriores, há um remanejamento entre os partidos. Aumenta significativamente a quantidade de ministros que não apresentam filiação partidária $(69,2 \%)$, refletindo no apoio parlamentar que cai de $74,3 \%$ para $47,2 \%$.

Eleito em 2002, o gabinete de Luiz Inácio Lula da Silva apresenta, até aquele momento, o maior número de pastas ministeriais do período republicano brasileiro, com vinte e três ministérios, um ministro de Estado extraordinário, sete órgãos ligados à Presidência com status ministerial e seis órgãos da Presidência sem status $^{20}$. O Banco Central também ganha status ministerial no primeiro mandato de

20 É acrescido o Ministério das Cidades e separaram-se o Ministério do Esporte e Turismo em Ministério do Esporte e Ministério do Turismo; assim como Ministério da Assistência Social e Previdência Social em Ministério da Assistência Social e Ministério da Previdência Social. Houve a criação de um Ministério de Estado Extraordinário de segurança Alimentar e Combate à Fome que, juntamente com o Ministério da Assistência Social, transformouse no Ministério do Desenvolvimento Social e Combate à Fome. No decorrer das gestões houve alguns rearranjos nos órgãos da Presidência e criou-se a Secretaria de Relações Institucionais. 
Lula (Medida Provisória no 207/2004).

Além de apresentar mais pastas, é o governo com maior número de partidos compondo a coalizão de governo do período republicano, em comparação com seus antecessores. Os nove partidos que compõem a coalizão representam 56,9\% da Câmara dos Deputados. Aqui a fragmentação partidária encontra paralelo na trajetória da estrutura do gabinete, embora outros aspectos relacionados à concepção ideológica de Estado possam ter igualmente influenciado nas transformações organizacionais, conforme mencionado anteriormente.

Tabela 5 - Composição partidária de pastas ministeriais e formação legislativa

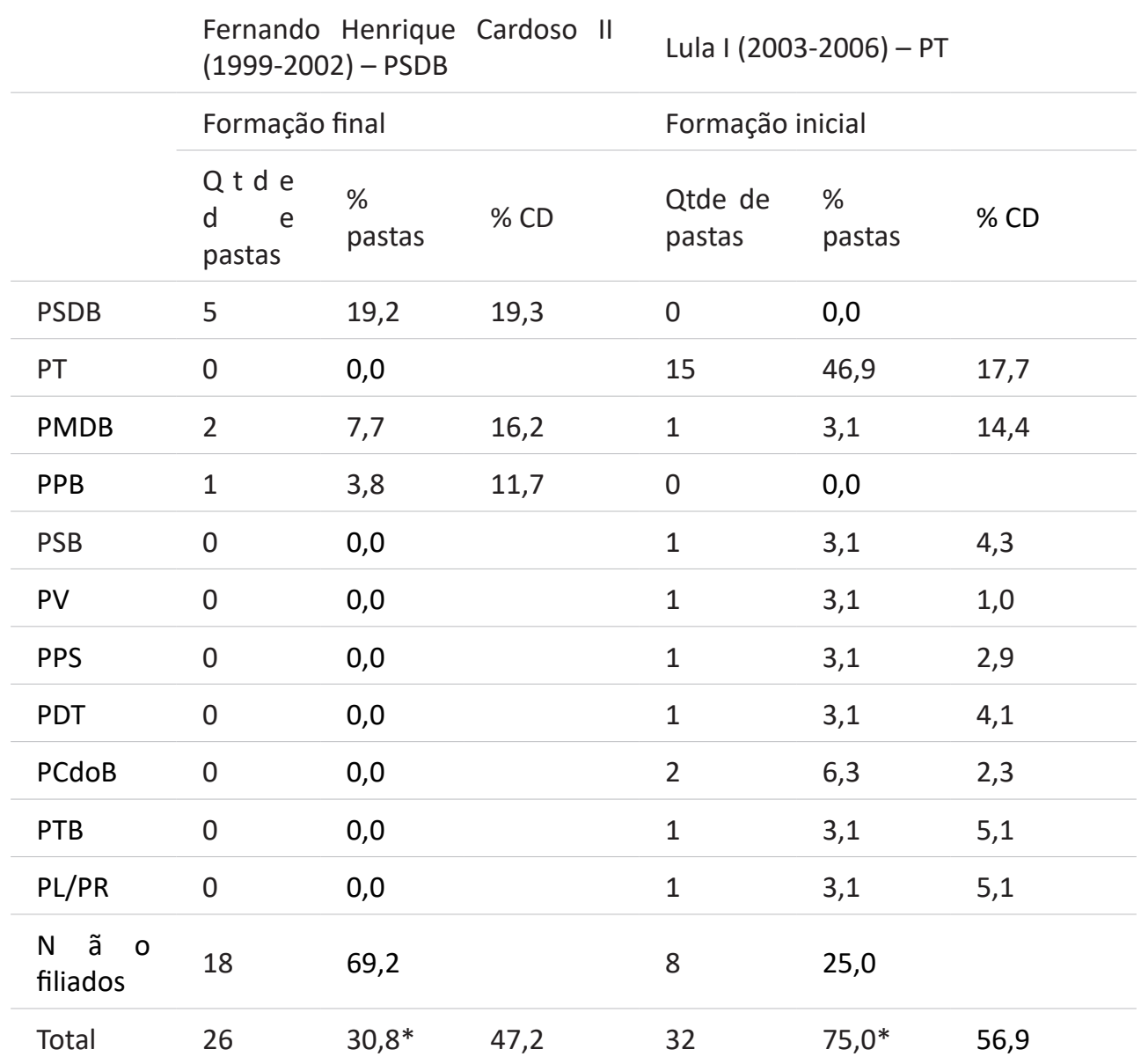

Fonte: elaboração própria a partir de dados da Biblioteca da Presidência da República e Câmara dos Deputados.

*É desconsiderado nesse total a porcentagem de pastas ocupadas por não filiados. 
Ao fim do primeiro mandato de Lula, é perceptível uma maior presença de ministros não filiados a partidos políticos (Tabela 6). Assim como não há muitas alterações nas pastas que compõem o governo durante a gestão, há algumas alterações pontuais na configuração partidária. Os órgãos ligados à Presidência, por sua vez, que sofreram algumas transformações em sua estrutura de gabinete, não sofreram mudança partidária. A gestão termina sendo composta por sete partidos, que representavam 49,9\% de cadeiras da Câmara dos Deputados.

Lula é reeleito e a composição do gabinete tem o acréscimo da Secretaria de Comunicação Social, ocupada por um não filiado, e da Secretaria de Planejamento de Longo Prazo, ocupada pelo Partido Republicano Brasileiro (PRB), que entra na coalizão. Seguindo a composição de seu governo anterior, havia a presença de oito siglas partidárias na coalizão do segundo mandato de Lula, que totalizam $47,8 \%$ dos assentos da Câmara dos Deputados. Ou seja, em cenário de elevada fragmentação partidária, o aumento do número de partidos na coalizão ainda não havia garantido a maioria na Câmara.

\section{Tabela 6 - Composição partidária de pastas ministeriais e formação legislativa}

\begin{tabular}{|c|c|c|c|c|c|c|}
\hline & \multicolumn{3}{|c|}{ Lula I (2003-2006) - PT } & \multicolumn{3}{|c|}{ Lula II (2007-2010) - PT } \\
\hline & \multicolumn{3}{|c|}{ Formação final } & \multicolumn{3}{|c|}{ Formação inicial } \\
\hline & $\begin{array}{l}\text { Qtde de } \\
\text { pastas }\end{array}$ & $\%$ pastas & $\% \mathrm{CD}$ & $\begin{array}{l}\text { Qtde de } \\
\text { pastas }\end{array}$ & $\begin{array}{l}\% \\
\text { pastas }\end{array}$ & $\% \mathrm{CD}$ \\
\hline PT & 11 & 36,7 & 17,7 & 11 & 34,4 & 16,2 \\
\hline PV & 1 & 3,3 & 1,0 & 1 & 3,1 & 2,3 \\
\hline PSB & 2 & 6,7 & 4,3 & 2 & 6,3 & 5,3 \\
\hline PMDB & 3 & 10,0 & 14,4 & 3 & 9,4 & 17,0 \\
\hline PCdoB & 1 & 3,3 & 2,3 & 1 & 3,1 & 2,5 \\
\hline PTB & 1 & 3,3 & 5,1 & 1 & 3,1 & 4,3 \\
\hline PR & 1 & 3,3 & 0,0 & 1 & 3,1 & 0,0 \\
\hline PRB & 0 & 0,0 & & 1 & 3,1 & 0,2 \\
\hline $\begin{array}{l}N \text { ã o } \\
\text { filiados }\end{array}$ & 10 & 33,3 & & 11 & 34,4 & \\
\hline Total & 30 & $66,7^{*}$ & 49,9 & 32 & $65,6^{*}$ & 47,8 \\
\hline
\end{tabular}

Fonte: elaboração própria a partir de dados da Biblioteca da Presidência da República e Câmara dos Deputados.

* É desconsiderado nesse total a porcentagem de pastas ocupadas por não filiados. 
Além disso, outra característica relevante de seu segundo mandato é que as pastas temáticas que eram ligadas à Presidência e sem status ministerial, tais como direitos humanos, política paras mulheres, portos e promoção da igualdade racial ganham status ministerial. A Secretaria de Pesca e Aquicultura transformase em Ministério da Pesca e Aquicultura. Assim, com a competência da Secretaria de Imprensa e Porta Voz transferida para a Secretaria de Comunicação Social, o segundo mandato de Lula encerra-se com todos os órgãos ligados à Presidência tendo status ministerial. Outro ponto que chama a atenção é como tais órgãos, com status ou não, em seus oito anos de governo, foram chefiados por filiados a partidos políticos. Em sua maioria, do partido do Presidente. Assim, além de a criação dessas secretarias ligadas diretamente ao presidente já dizerem sobre sua plataforma programática, elas trazem indícios de interesse de maior controle e acompanhamento dessas agendas temáticas.

Dilma herda a estrutura ministerial do governo Lula e inicia sua gestão com vinte e quatro ministérios e treze órgãos ligados à Presidência com status ministerial. Ela acrescenta a Secretaria de Aviação Civil. Seu governo, seguindo o padrão de seu antecessor, apresenta uma substancial coalizão de governo, com oito partidos, que representam 63,4\% de cadeiras da Câmara dos Deputados. Além disso, o Partido dos Trabalhadores (PT), partido da presidenta, ocupava dezessete dos trinta e oito ministérios e órgãos (Tabela 7).

Quando comparado com a formação final do governo Lula, há aumento de representatividade de algumas siglas, somando 63,4\% das cadeiras da Câmara dos Deputados. Isso é acompanhado por um aumento na estrutura do gabinete, ainda que tenha sido criada apenas uma secretaria ligada à Presidência com status de ministério. 
Tabela 7 - Composição partidária de pastas ministeriais e formação legislativa

\begin{tabular}{|c|c|c|c|c|c|c|}
\hline & \multicolumn{3}{|c|}{ Lula II (2007-2010) - PT } & \multicolumn{3}{|c|}{ Dilma I (2011-2014) - PT } \\
\hline & \multicolumn{3}{|c|}{ Formação final } & \multicolumn{3}{|c|}{ Formação inicial } \\
\hline & $\begin{array}{l}\text { Qtde de } \\
\text { pastas }\end{array}$ & $\%$ pastas & $\% C D$ & $\begin{array}{l}\text { Qtde de } \\
\text { pastas }\end{array}$ & $\begin{array}{l}\% \\
\text { pastas }\end{array}$ & $\% \mathrm{CD}$ \\
\hline PT & 13 & 35,1 & 16,2 & 17 & 44,7 & 17,2 \\
\hline PMDB & 6 & 16,2 & 17,0 & 6 & 15,8 & 15,2 \\
\hline PV & 1 & 2,7 & 2,3 & 0 & 0,0 & \\
\hline PP & 0 & 0,0 & & 1 & 2,6 & 8,6 \\
\hline PCdoB & 1 & 2,7 & 2,5 & 1 & 2,6 & 2,9 \\
\hline PDT & 1 & 2,7 & 4,9 & 1 & 2,6 & 5,1 \\
\hline PSB & 2 & 5,4 & 5,3 & 1 & 2,6 & 6,6 \\
\hline PR & 1 & 2,7 & 0,0 & 1 & 2,6 & 7,8 \\
\hline PROS & 0 & 0,0 & 0,0 & 1 & 2,6 & 0,0 \\
\hline Não filiados & 12 & 32,4 & & 9 & 23,7 & \\
\hline Total & 37 & $67,6^{*}$ & 48,1 & 38 & $76,3^{*}$ & 63,4 \\
\hline
\end{tabular}

Fonte: elaboração própria a partir de dados da Biblioteca da Presidência da República e Câmara dos Deputados.

*É desconsiderado nesse total a porcentagem de pastas ocupadas por não filiados.

No decorrer de seu primeiro mandato, além da transformação do Ministério da Ciência e Tecnologia, com inclusão do tema inovação, é criada também a Secretaria Especial da Micro e Pequena Empresa, ligada à Presidência, com status ministerial. Essa secretaria passa a ser ocupada pelo PSD e seu governo termina com a inserção de mais um partido e acréscimo de pasta ministerial, bem como rearranjos partidários pontuais.

Reeleita em 2014, Dilma mantém a mesma estrutura ministerial de seu governo anterior, mas conta com a maior coalizão observada nos governos da República brasileira, com dez partidos, representando 63,9\% de assentos da Câmara dos Deputados. Ou seja, não houve expansão do gabinete para acomodar novas siglas partidárias da coalizão, mas sim o rearranjo entre pastas e partidos como PT, PMDB e PP cedendo espaços aos demais partidos. 
Tabela 8 - Composição partidária de pastas ministeriais e formação legislativa

\begin{tabular}{|c|c|c|c|c|c|c|}
\hline & \multicolumn{3}{|c|}{ Dilma I (2011-2014) - PT } & \multicolumn{3}{|c|}{ Dilma II (2015-2016) - PT } \\
\hline & \multicolumn{3}{|c|}{ Formação final } & \multicolumn{3}{|c|}{ Formação inicial } \\
\hline & $\begin{array}{l}\text { Qtde de } \\
\text { pastas }\end{array}$ & $\%$ pastas & $\% C D$ & $\begin{array}{l}\text { Qtde de } \\
\text { pastas }\end{array}$ & $\begin{array}{l}\% \\
\text { pastas }\end{array}$ & $\% C D$ \\
\hline PT & 15 & 38,5 & 17,2 & 13 & 33,3 & 13,3 \\
\hline PMDB & 4 & 10,3 & 15,2 & 6 & 15,4 & 12,7 \\
\hline PP & 2 & 5,1 & 8,6 & 1 & 2,6 & 7,4 \\
\hline PDT & 1 & 2,6 & 5,1 & 1 & 2,6 & 3,9 \\
\hline PTB & 0 & 0,0 & & 1 & 2,6 & 4,9 \\
\hline PSD & 1 & 2,6 & 0,0 & 2 & 5,1 & 7,0 \\
\hline PCdoB & 1 & 2,6 & 2,9 & 1 & 2,6 & 1,9 \\
\hline PROS & 1 & 2,6 & 0,0 & 1 & 2,6 & 2,1 \\
\hline PRB & 1 & 2,6 & 1,6 & 1 & 2,6 & 4,1 \\
\hline$P R$ & 2 & 5,1 & 7,8 & 1 & 2,6 & 6,6 \\
\hline Não filiados & 11 & 28,2 & & 11 & 28,2 & \\
\hline Total & 39 & $71,8^{*}$ & 58,3 & 39 & $71,8^{*}$ & 63,9 \\
\hline
\end{tabular}

Fonte: elaboração própria a partir de dados da Biblioteca da Presidência da República e Câmara dos Deputados.

*É desconsiderado nesse total a porcentagem de pastas ocupadas por não filiados.

Sob pressões quanto à necessidade de reforma ministerial e necessidade de ajuste fiscal, com a Medida Provisória no 696, de outubro de 2015, Dilma realiza uma reforma ministerial, em que há a extinção do Ministério de Pesca e Aquicultura, assim como do Ministério do Trabalho e Ministério da Previdência Social, que são condensados em um. As Secretarias de: Mulheres, Igualdade Racial e Direitos Humanos são aglutinadas no Ministério das Mulheres, da Igualdade Racial, da Juventude e dos Direitos Humanos. Órgãos ligados à Presidência, em que havia status ministerial, como Secretaria de Assuntos Estratégicos, Secretaria de Relações Institucionais, Secretaria da Micro e Pequena Empresa, são extintos.

Seu mandato, pós reforma, termina com uma retração em sua estrutura organizacional que permanece no governo Temer (Tabela 9). Contudo, como apontam Barbosa e Pompeu (2017), embora tenha havido a diminuição do número de pastas ministeriais, a estrutura abaixo é conservada em processos de aglutinação. Ainda que limitada a um período de análise mais recente, essa informação é 
interessante por indicar que os decréscimos, em uma curva de expansão, podem não representar, de fato, diminuição da administração pública.

Apesar de o mandato de Dilma encerrar com uma coalizão de seis partidos, há um percentual relativamente alto de pastas chefiadas pelo partido do Presidente $(37,5 \%)$ e não filiados (37,5\%). Este último somente é inferior ao observado no Governo Itamar (77\%) e no segundo governo FHC, que chega a 69\%. Essa configuração estrutural e partidária pode ser explicada, em alguma medida, pela crise política que se instaurou no Brasil em 2016. Em meio a controvérsias quanto à legitimidade do processo de impeachment, Dilma é afastada em maio de 2016. Michel Temer ocupa o cargo interinamente e assume a Presidência definitivamente em agosto de 2016.

Tabela 9 - Composição partidária de pastas ministeriais e formação legislativa

\begin{tabular}{|c|c|c|c|c|c|c|}
\hline & \multicolumn{3}{|c|}{ Dilma II (2015-2016) - PT } & \multicolumn{3}{|c|}{ Temer (2016-2018) - PMDB } \\
\hline & \multicolumn{3}{|c|}{ Formação final } & \multicolumn{3}{|c|}{ Formação inicial } \\
\hline & $\begin{array}{l}\text { Qtde de } \\
\text { pastas }\end{array}$ & $\%$ pastas & $\% C D$ & $\begin{array}{l}\text { Qtde de } \\
\text { pastas }\end{array}$ & $\begin{array}{l}\% \\
\text { pastas }\end{array}$ & $\% \mathrm{CD}$ \\
\hline PT & 12 & 37,5 & 13,3 & 0 & 0,0 & \\
\hline PMDB & 3 & 9,4 & 12,7 & 7 & 25,9 & 12,7 \\
\hline PDT & 1 & 3,1 & 3,9 & 0 & 0,0 & \\
\hline PTB & 1 & 3,1 & 4,9 & 0 & 0,0 & \\
\hline PCdoB & 2 & 6,3 & 1,9 & 0 & 0,0 & \\
\hline PR & 1 & 3,1 & 6,6 & 0 & 0,0 & \\
\hline PSDB & 0 & 0,0 & & 2 & 7,4 & 10,5 \\
\hline PV & 0 & 0,0 & & 1 & 3,7 & 1,6 \\
\hline DEM & 0 & 0,0 & & 1 & 3,7 & 4,1 \\
\hline PPS & 0 & 0,0 & & 1 & 3,7 & 1,9 \\
\hline PRB & 0 & 0,0 & & 1 & 3,7 & 4,1 \\
\hline PSB & 0 & 0,0 & & 1 & 3,7 & 6,6 \\
\hline PP & 0 & 0,0 & & 2 & 7,4 & 7,4 \\
\hline PSD & 0 & 0,0 & & 1 & 3,7 & 7,0 \\
\hline Não filiado & 12 & 37,5 & & 10 & 37,0 & \\
\hline Total & 32 & $62,5^{*}$ & 43,3 & 27 & $63,0^{*}$ & 55,9 \\
\hline
\end{tabular}

Fonte: elaboração própria a partir de dados da Biblioteca da Presidência da República e Câmara dos Deputados.

* É desconsiderado nesse total a porcentagem de pastas ocupadas por não filiados. 
Ao assumir interinamente, Michel Temer edita uma Medida Provisória, no 726/2016, e altera a organização do Poder Executivo, diminuindo a quantidade de ministérios e órgãos ligados diretamente à Presidência. Ainda que tenha diminuído o número de pastas ministeriais, a coalizão de governo volta a crescer em número de partidos (nove partidos), que representam $55,9 \%$. O desembarque do governo dos partidos PT, PDT, PTB, PCdoB e PR, que no governo Dilma ocupavam 17 pastas, bem como a redução do número de filiados a partidos políticos à frente de pastas ministeriais, viabilizaram, além da redução do número de pastas, espaço suficiente para o aumento da ocupação do PMDB e ainda a inclusão de novos partidos na coalizão.

\section{Considerações finais}

A trajetória da estrutura organizacional, observada na formação do gabinete, da administração pública federal (direta) durante os governos democráticos entre 1945 e 2016 demarca diferenças entre os períodos intercalados pela ditadura militar. 0 primeiro período, que se estende do Governo Dutra ao segundo governo de João Goulart, é caracterizado por um reduzido número de partidos nas coalizões, sendo estas mais estáveis entre governos. Nesse contexto, a estrutura organizacional da administração direta tende a ser estável com pequenos incrementos no número de pastas ministeriais, à exceção do Governo Goulart, que encerra seu mandato com um acréscimo de três pastas ministeriais, em relação ao governo anterior.

O segundo período, que segue do Governo Sarney ao início do mandato de Michel Temer, é marcado por crescente fragmentação partidária e coalizões de governo mais extensas, em número de partidos, nas transições de governos. Nesse cenário de maior pressão pela distribuição de poder entre um maior número de atores, a estrutura da administração pública federal (direta) segue uma trajetória marcada por expressivo aumento do número de pastas ministeriais e até mesmo o surgimento de órgãos da Presidência com status de ministério, a partir do governo Sarney, e do Banco Central (autarquia) como pasta ministerial desde o primeiro Governo Lula, sinalizando maior interesse por controle da agenda governamental em cenário de coalizões mais extensas em número de partidos.

Exceção a essa tendência de aumento da coalizão de governo e incrementos no número de pastas ministeriais são as transições de Sarney para Collor e de Dilma II para Temer. No caso da transição do Governo Sarney para o Governo Collor, ainda que tenha havido um aumento de dois partidos na coalizão de governo, Collor não chega a obter maioria no Congresso. Desse modo, as alterações na composição da coalizão não parecem se tratar de uma coalizão de governo nos termos de Figueiredo (2007). Ou seja, a formação do gabinete não foi realizada com vistas a garantir maioria no Congresso e teve uma elevada quantidade de 
pastas ocupadas por não filiados (61,5\%). Nesses casos, outros fatores contextuais podem ter influenciado essas alterações atípicas. Sem um vínculo forte com o legislativo, entre criações e extinções, Collor reduz sete pastas ministeriais no gabinete, quando comparado com a formação final de Sarney. Destaca-se que não se observou no governo Collor estratégia clara quanto às transformações realizadas na administração pública federal, que chegam a ser mencionadas pela literatura do campo como um desmantelamento do aparelho do Estado. Nesse contexto e com seu mandato encerrado por um processo de impeachment, o governo Collor se mostra totalmente atípico quanto à trajetória estrutural da administração direta do Poder Executivo federal.

O Governo Temer, que executa, logo de início, drástica redução no número de pastas ministeriais, o faz em um contexto de aumento do número de partidos na coalizão em relação ao governo anterior, que passa de seis para nove partidos. As pastas são distribuídas de forma bastante pulverizada, tendo o PMDB, partido do presidente, sete pastas. Contudo, o cenário é bastante peculiar, pois o governo anterior registrava o ápice do número de pastas compondo o gabinete (trinta e nove) e elevado número de pastas que antes foram ocupadas pelo Partido dos Trabalhadores (doze). Com a reforma ministerial e o processo de impeachment, o Governo Dilma Rousseff encerra-se com parcela significativa de pastas ocupadas pelo partido da presidente e não filiados. Assim, o Governo Temer recebe pastas suficientes para acomodar mais três partidos e ainda reduzir o volume de pastas ministeriais. Em relação ao governo Dilma Rousseff, a estratégia adotada por Temer foi reduzir a participação do partido do Presidente no gabinete e pulverizar as demais pastas entre os partidos da coalizão.

Merecem destaque também alguns movimentos com alterações nas coalizões de governo e na estrutura do gabinete que ocorreram no decorrer dos mandatos. No Governo JK, primeiro governo de Goulart, segundo governo FHC e segundo governo Lula ocorrem reduções do número de partidos na coalizão e, ainda assim, houve aumentos na composição estrutural do gabinete, o que aponta mais para questões de agenda do que de distribuição de poder no âmbito da coalizão. Por fim, há o caso do primeiro mandato Lula, no qual ocorre redução do número de partidos na coalizão, abrindo espaço para a redução do número de pastas ministeriais.

Diante do quadro geral e ainda considerando as exceções acima expostas, é possível afirmar que as trajetórias das coalizões de governo e da estrutura da administração direta do Poder Executivo federal estão correlacionadas. Em geral, o aumento do número de partidos na coalizão é acompanhado por aumento do número de pastas ministeriais. De outro lado, diminuições do número de partidos nas coalizões são paralelas à diminuição ou manutenção da composição do gabinete. 
Contudo, cabe esclarecer que não se objetivou estabelecer relação de causalidade, mas sim descrever o comportamento da trajetória organizacional em contexto de fragmentação partidária e coalizões de governo cada vez maiores.

O caráter exploratório da pesquisa reflete a incipiente literatura sobre o tema, que visa problematizar o aspecto estrutural dos mandatos. Considerando a correlação acima observada, destaca-se a necessidade de um olhar mais detalhado, por meio de estudos adicionais, sobre aspectos tais como a estabilidade estrutural, traços técnicos e políticos nas transformações observadas e seus efeitos sobre os resultados da ação governamental.

A partir desse mapeamento inicial, outras questões se colocam no âmbito de um projeto de pesquisa mais amplo. Entender melhor a dinâmica da trajetória organizacional implica em investigar também as questões de ordem temática que refletem sobre a agenda governamental, a tendência de distribuição orçamentária e de força de trabalho entre pastas ministeriais, bem como efeitos de ajustes fiscais sobre a organização da administração pública. Compreender tal dinâmica tornase relevante na medida em que a dimensão estrutural dos governos se relaciona também com a capacidade de gerenciamento e oferta de políticas públicas, ou seja, com a promoção e elevação do bem-estar social.

\section{Referências bibliográficas}

AMORIM NETO, O. Gabinetes presidenciais, ciclos eleitorais e disciplina legislativa no Brasil. Dados, Rio de Janeiro, v. 43, n. 3, p. 479-519, 2000.

Amorim Neto, O. Presidencialismo e governabilidade nas Américas. 1. ed. Rio de Janeiro: Editora FGV, 2006.

Amorim Neto, O.; Cox, G.; McCubbins, M. Agenda power in Brazil's Câmara dos Deputados (1989-98). World Politics, Princeton, v. 55, n. 4, p. 1-46, 2003.

BARBOSA, S.; POMPEU, J. Trajetória recente da organização do Governo Federal. Boletim de Análise Político-Institucional do Instituto de Pesquisa Econômica Aplicada, n. 12, jul./dez., 2017.

BiblioteCA dA PRESIDÊNCIA dA RepúblicA. Galeria de ex Presidentes. Disponível em: <http://biblioteca.presidencia.gov.br/presidencia/ex-presidentes $>$. Acesso em 14/06/2017.

BATISTA, M. O mistério dos ministérios: a governança da coalizão no presidencialismo brasileiro. Tese de doutorado em Ciência Política - Universidade Federal de Pernambuco, Recife, 2014.

BERSCH, K.; PRAÇA, S.; TAYLOR, M. State capacity and bureaucratic autonomy within national States: Mapping the Archipelago of Excellence in Brazil. The Latin American Studies Association Conference, Washington D. C, may/jun, 2013.

BRYNER, G. Organizações públicas e políticas públicas. In: PETERS, B. G; PIERRE, J (Orgs.). Administração pública: coletânea. São Paulo: Ed. UNESP; Brasília: ENAP, 
2010.

Centro de Pesquisa e Documentação de História Contemporânea do Brasil da FundAÇÃo GETÚlIo VARGAS (CPDOC-FGV). Dicionário Histórico-Biográfico Brasileiro (DHBB). Disponível em: <http://cpdoc.fgv.br/acervo/dhbb> Acesso em 14/06/2017.

CHEIBUB, J.; LIMONGI, F. Democratic institutions and regime survival: parliamentary and presidential democracies reconsidered. Annual Review of Political Science, v. 5, n. 1, p. 151-179, 2002.

COSTA, F. Brasil: 200 anos de Estado; 200 anos de administração pública; 200 anos de reformas. Revista de Administração Pública, Rio de Janeiro, v. 42, n. 5, p. 829874 , oct., 2008.

DARRIEUX, R. Sucessos de governo no Brasil: habilidades ou instituições? Dissertação de mestrado em Ciência Política - Instituto de Estudos Sociais e Políticos, Universidade do Estado do Rio de Janeiro, Rio de Janeiro, 2015.

DAVIS, G.; Weller, P.; CRASWELL, E.; EgGINS, S. What drives machinery of government change? Australia, Canada and the United Kingdom? Public Administration, v. 77, p. 7-50, 1999.

Figueiredo, A. Government coalitions Brazilian democracy. Brazilian Political Science Review, São Paulo, v. 1, n. 2, p. 182-216, 2007.

GAYLORD, S.; RENNó, L. Opening the black box: cabinet authorship of Legislative proposals in a multiparty presidential system. Presidential Studies Quarterly, v. 45, p. 247-269, 2015.

HALL, R. Organizations: structures, processes and outcomes. Englewood Cliffs, N.J.: Prentice-Hall, ed. 4, 1996.

HIPPOLITO, L. De raposas e reformistas: o PSD e a experiência democrática brasileira, 1945-64. Rio de Janeiro: Paz e Terra, 1985.

Howlett, Michael; Ramesh, M; Perl, Anthony. Política pública: seus ciclos e subsistemas: uma abordagem integral. Rio de Janeiro: Elsevier, 2013

INÁCIO, M. Entre presidir e coordenar: Presidência e gabinetes multipartidários no Brasil. 3o Encontro Latino-Americano de Ciência Política. Campinas, 2006.

INÁCIO, M.; LLANOS, M. The institutional presidency in Latin America: a comparative analysis. Presidential Studies Quarterly, v. 46, n. 3, p. 531-549, 2016.

INÁcio, M.; ReZEndE, D. Partidos legislativos e governo de coalizão: controle horizontal das políticas públicas. Opinião Pública, Campinas, v. 21, n. 2, ago, 2015.

LAAKSO, M.; TAAGEPERA, R. "Effective" number of parties: a measure with application to Western Europe. Comparative Political Studies, v. 12, n.1, p. 3-27, 1979.

LIMONGI, F.; FIgUEIREDO, A. Bases institucionais do presidencialismo de coalizão. Lua Nova [online]. n. 44, p. 81-106. 1998.

Limongl, F.; Figueiredo, A. A crise atual e o debate institucional. Novos Estudos. Cebrap. São Paulo, v. 36, n. 3, p.79-97, 2017.

LINZ, J. Democracy: Presidential or Parliamentary. Does it make a difference? Paper prepared for the project, "The Role of Political Parties in the Return to Democracy 
in the Southern Cone," sponsored by the Latin American Program of the Woodrow Wilson International Center for Scholars, and the World Peace Foundation, 1985.

MAINWARING, S.; SHUGART, M. Presidencialismo y democracia en América Latina: revisión de los términos del debate. In: MAINWARING, S.; SHUGART, M (comp.), Presidencialismo y democracia en América Latina. Buenos Aires: Padiós Latinoamericana, 2002.

MARTINEZ-Gallardo, C. Inside the Cabinet: the influence of ministers in the policymaking process. In: SCARTASCINI, C.; STEIN, E.; TOMMASI, M. (eds.). How Democracy Works: Political institutions, actors, and arenas in Latin American Policymaking, 1. Washington: Inter-American Development Bank, p. 119-45, 2010.

Pereira, C.; POWER, T; RAILE, E. Presidentialism, coalitions and accountability. In: POWER, T.; TAYLOR, M (eds). Corruption and Democracy in Brazil: the struggle for accountability. University of Notre Dame Press, 2011.

Public Administrative Select Committee. Machinery of Government Changes: 7th Report. House of Commons Publication HC 672. London: The Stationary Office, 2007.

RENNó, L.; WoJCIK, S. The changing role of ministers in the Legislative agenda in Brazil. Revista Iberoamericana de Estudos Legislativos, v. 4, p. 57, 2015.

TACHIZAWA, T.; SCAICO, O. Organização flexível: qualidade na gestão por processos. São Paulo: Editora Atlas SA, 2 ed, 2006.

VIEIRA, M. Como o conflito de políticas do gabinete afeta a criação de burocracias públicas centralizadas na presidência? Anais do Encontro Anual da Associação Brasileira de Ciência Política, Brasília, 2014.

White, A.; DUNLEAVY, P. Making and breaking Whitehall departments: a guide to machinery of government changes. Institute for Government, LSE Public Policy Group, London, UK, 2010.

Jaqueline da Silva Borges

Mestre em Ciência Política. Pesquisadora assistente na Diretoria de Estudos e Políticas do Estado, das Instituições e da Democracia (DIEST) do IPEA.

Sheila Cristina Tolentino Barbosa

Doutora em Administração. Especialista em Políticas Públicas e Gestão Governamental na DIEST/IPEA e professora do Departamento de Gestão de Políticas Públicas da Universidade de Brasília (UnB). 